\title{
BGAパッケージはんだ接合部の疲労強度評価
}

\author{
海老原 理徳 ${ }^{*}$, 小俣 宣行 ${ }^{* *}$, 茂木 正徳 ${ }^{* * *}$, 中村 直樹***, 酒井 秀久 ${ }^{* * *}$
}

\section{Fatigue Strength Evaluation of BGA Package Solder Joints}

Yoshinori EBIHARA*, Nobuyuki OMATA ${ }^{* *}$, Masanori MOTEGI ${ }^{* * *}$, Naoki NAKAMURA ${ }^{* *}$ and Hidehisa SAKAI ${ }^{* * *}$

*東京学芸大学第 4 部（下 184-0015 東宗都小金井书貫井北町4-1-1）

**東京学坛大学大学院（テ184-0015 東京都小金井市貫牛北町4-1-1）

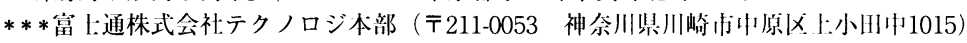

*4th Division, Tokyo Gakugei Univ. (4-1-1 Nukuikitamachi, Koganei-shi, Tokyo 184-0015)

**Graduate School, Tokyo Gakugei Univ. (4-1-1 Nukuikitamachi, Koganei-shi, Tokyo 184-0015)

***Technology Group, Fujitsu Ltd. (1015 Kamiodanaka, Nakahara-ku, Kawasaki-shi, Kanagawa 211-0053)

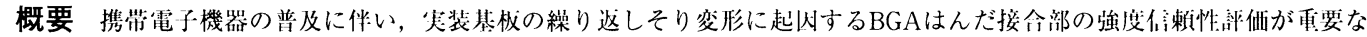

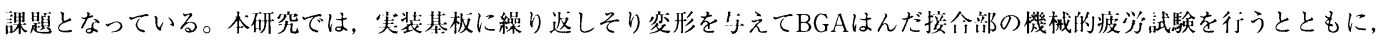

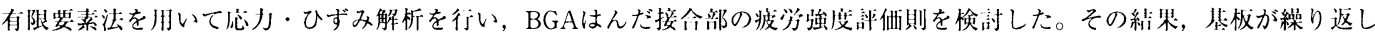

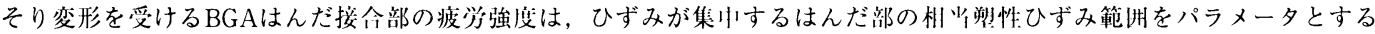

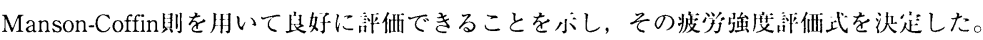

\begin{abstract}
Fatigue strength evaluation of BGA solder joints under cyclic bending of printed circuit boards was studied. Mechanical fatigue tests of BGA solder joints by cyclic bending of printed circuit boards were done. In addition, stress-strain analysis of BGA solder joints using finite element method was made and fatigue strength evaluation law was studied. As a result, it was shown that fatigue strength of BGA solder joints under cyclic bending of printed circuit boards, was evaluated well by Manson-Coffin's law using equivalent plastic strain range as fatigue parameters. Finally the fatigue strength evaluation equation was determined.
\end{abstract}

Key Words: Ball Grid Array Package, Solder Joint, Fatigue, Printed Circuit Board, Bending

\section{1. 緒 言}

ICパッケージの高密度化の流れの中でBall Grid Array パッケージ（以下BGA）が注目されている。BGAは格子 状に並んだ微小なはんだバンプによってプリント回路板に 接合されることから，QFPに比べてピッチを微細化せず に多ピン化が容易であり，高実装精度を必要としないなど の利点を有する。ところがBGAはんだ接合部では，周期 的な温度環境下において，パッケージ基板，Siチップ，プ リント配線板の線膨張係数の違いに基づく変位のミスマッ チにより周期的な熱応力がはんだ接合部に加わり, 疲労破 壊が生じる。したがってBGAパッケージの設計では，は んだ接合部の熱瘦労強度評価が重要な検討課題の1つであ り，この問題に関して多くの研究が行われている ${ }^{12 ! 2)}$

一方, 携帯電話やノートパソコンなどの携帯電子機器の 普及に伴い，その携帯移動時の曲げなどによる繰り返し変 形に起因する各部の疲労破壊に関する問題が注目されてい る。BGAはんだ接合部においても，他の電子部品はんだ 接合部と同様に，実装基板の繰り返しそり変形に起因する
疲労破壊が生じ，その強度信頼性評価が重要な課題となっ ている。ところが実装基板の繰り返しそり变形に起因する BGAはんだ接合部の疲労強度評価に関する研究は非常に 少ないのが現状である。

そこで本研究では, 実装基板に繰り返しそり変形を与え てBGAはんだ接合部の機械的疲労試験を行い, 破断まで の寿命を測定するとともに, 疲労試験に対応した有限要素 法による応力・ひずみ解析を行い，BGAはんだ接合部の 疲労強度評価則を検討し, 疲労強度評価式を求めた。

\section{2. 機械的疲労試験}

実装基板に繰り返しそり変形を与えてBGAはんだ接合 部の機械的疲労試験を行った。疲労試験に用いた試験片の 形状と寸法を図 1 に, BGAパッケージの形状と寸法を図 2 に，はんだバンプ部の拡大図を図 3 にそれぞれ示す。試 験片はBGAパッケージを15行15列225個の格子状のはんだ バンプを用いてプリント回路板の片面中央にはんだ付けし たものである。実装に用いたはんだ材は共晶はんだ(63Sn$37 \mathrm{~Pb})$ である。プリント回路板はFR-4製で，板厚が $0.5 \mathrm{~mm}$ 


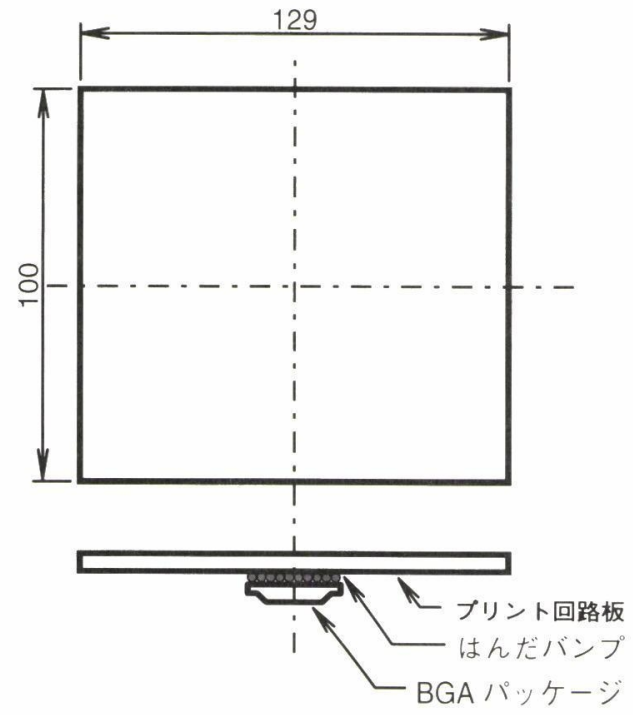

図1. 試験片の形状と寸法
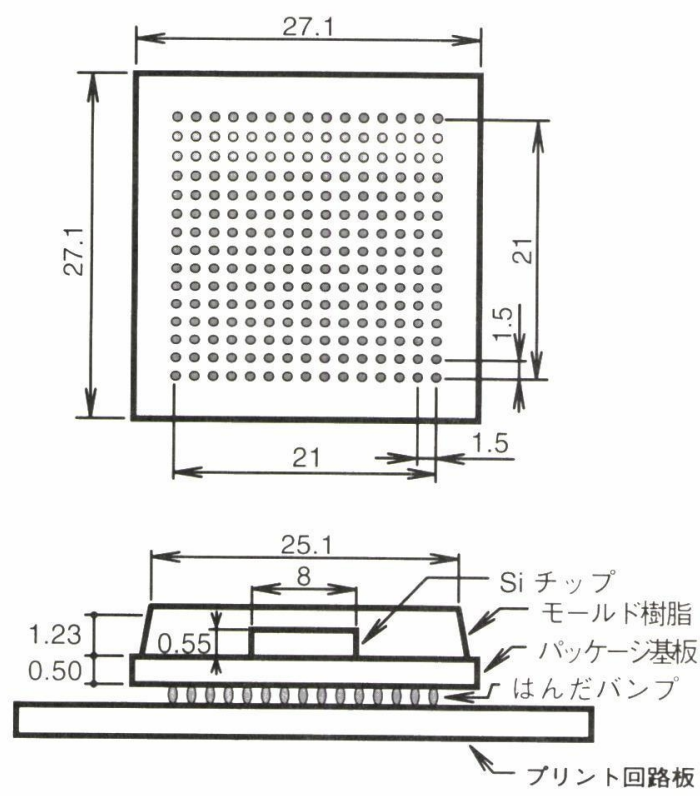

図2. BGAパッケージの形状と寸法

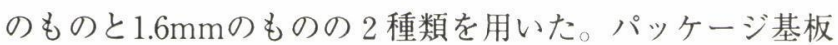
材料はBTレジンである。

次に, 機械的疲労試験の概略を図 4 に示す。疲労試験は 図 4 で, プリント回路板の長手方向の両端をスパン $100 \mathrm{~mm}$ で支持し，プリント回路板の中心をBGAが実装さ れた面の裏側から引張試験機に取り付けた治具を用いて周 期的に押すことにより行った。基板中心におけるたわみと 経過時間の関係を図 5 に示す。図 5 で治具の上下速度は 2 $\mathrm{mm} / \mathrm{sec}$ 一定とし, 最大たわみを変えた 5 つの負荷条件を 用いて疲労試験を行った。引張試験機はINSTRON製5567 を用いた。

はんだ接合部における破断の発生は電気的な導通千ェッ クにより調べた。疲労試験後のはんだバンプ断面の例を図 6 に示す。図6 からき裂は図の右下，はんだバンプとプリ ント回路板の界面端近傍のはんだ側から発生していること

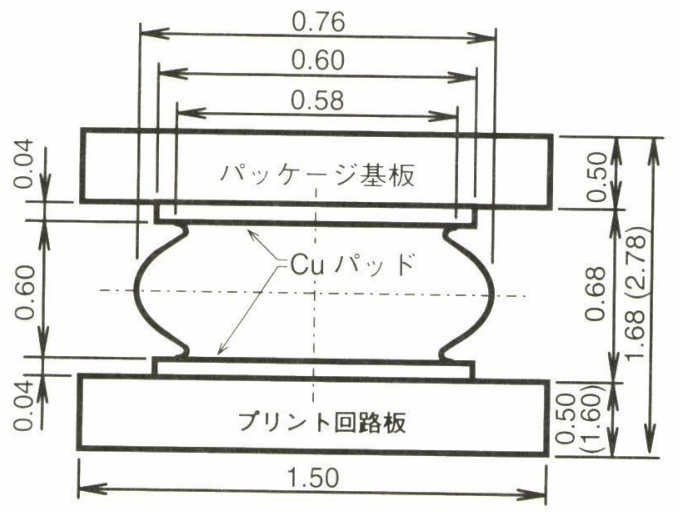

図3.はんだバンプ部の拡大図

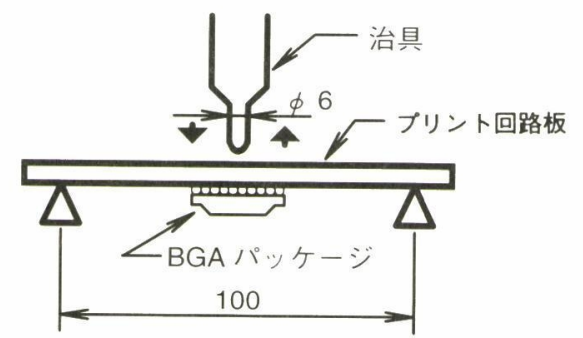

図4. 機械的疲労試験

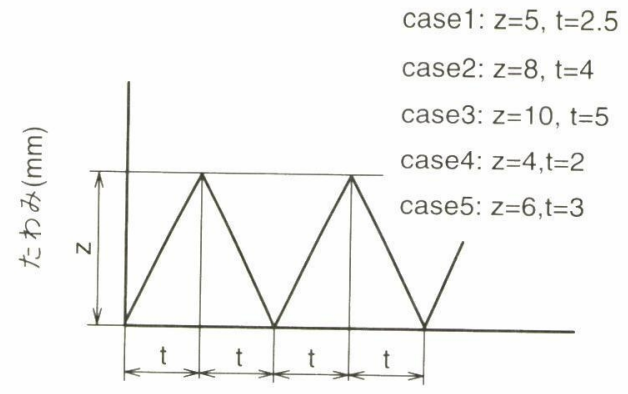

時間 $(\mathrm{sec})$

図5．基板中心のたわみと時間の関係

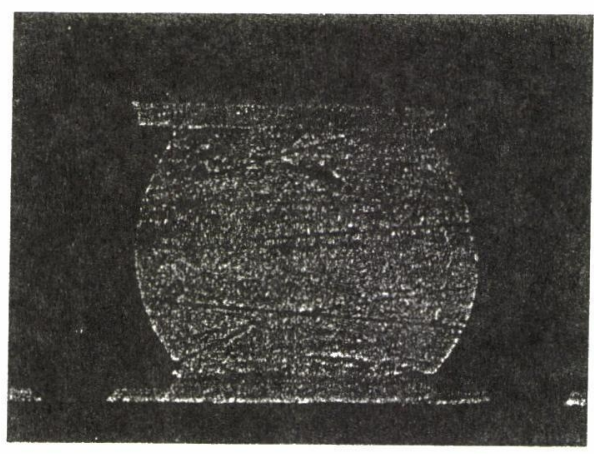

図6. 疲労試験後のはんだバンプ断面の例

がわかる。疲労試験から得られた破断発生までの疲労寿命 を表 1 に示す。

\section{BGAはんだ接合部の応力・ひずみ解析}

解析は全体解析と詳細解析の 2 段階に分けて行った。ま ず全体解析として, 試験片全体を解析対象として機械的疲 労試験に対応した 3 次元弾性解析を行い, 基板各部の变位 とはんだバンプに生じるひずみを求めた。次に，全体解析 で相当ひずみが最大になったはんだバンプ 1 個分とその周 
表1，疲労試験結果

\begin{tabular}{|c|c|c|c|}
\hline 試験 & $\begin{array}{c}\text { ブリント } \\
\text { [!门]路板の接さ } \\
{[\mathrm{mm}]}\end{array}$ & $\begin{array}{c}\text { 最人たわみ } \\
{[\mathrm{mm}]}\end{array}$ & $\begin{array}{l}\text { 将学㚘命 } \\
\text { [サイクル }\end{array}$ \\
\hline case1 & 0.5 & 5 & 2013 \\
\hline case 2 & 0.5 & 8 & 358 \\
\hline case 3 & 0.5 & 10 & 71 \\
\hline case 4 & 1.6 & 4 & 168 \\
\hline case5 & 1.6 & 6 & 58 \\
\hline
\end{tabular}

辺の基板を解析対象として詳細解析モデルを作成し，全体 解析で求めた基板の変位を強制変位として与え，はんだの み塑性を考慮して 3 次元弾塑性解析を行った。これらの解 析からはんだバンプに生じる相当塑性ひずみ範囲を求め た。解析には沉用有限要素法解析コードMARCを用いた。

\section{1 全体解析}

試験片全体を解析対象とし，すべての材料を弾性体と仮 定して 3 次元弾性解析を行った。本解析は，ひずみが集中 するはんだバンプ周辺の基板の変位を求めることが目的で あるため，使用計算機の能力を考慮し，はんだを弾性体と 仮定して解析を行った。また同様の理由でSiチップを省略 してモデル化した。解析に使用した材料定数を表 2 に示す。

解析は対称性を考虑して全体の 4 分の 1 について行っ た。プリント回路板，パッケージ基板およびモールド樹脂 は 4 節点線形シェル要素, はんだバンプは 2 節点 3 次元弾 性はり要素を用いてモデル化した。全体解析の要素分割図 を図 7 に，はんだバンプ周辺の要素分割拡大図を図 8 にそ れぞれ示す。図 7 で，点Oがプリント回路板の中心，辺 OA，OCが対象軸，O'DEFはパッケージ基板である。辺 $\mathrm{OA}$ 上の節点についてはy軸方向変位と $\mathrm{x}$ 軸および $\mathrm{z}$ 軸回り の回転角を，辺OC上の節点についてはx軸方向変位と $\mathrm{y}$ 軸 および $z$ 軸回りの回転角をそれぞれ拘束した。辺 $A B$ は $z$ 軸 方向変位を拘束した。解析では点 $\mathrm{O}$ 近傍の節点に時間の経 過に合わせて強制変位を与え, 疲労試験をモデル化した。

シェル要素によるモデル化では, 厳密には解析対象の板 厚の中立面がシェル要素の存在する面となるようにモデル 化すべきところである。しかし今回の解析ではシェルの理 論に忠実にモデル化しょうとすると，解析対象の形状から 基板の板厚の分だけはんだバンプの高さが増えてしまう。 本解析においては基板よりも疲労破壊が発生するはんだを 重視してモデル化すべきだと考えた。そこで基板をシェル 要素でモデル化するにあたっては，パッケージ基板，プリ

表2. 解析に使用した材料定数（室温）

\begin{tabular}{l|c|c}
\hline \multicolumn{1}{c|}{ 材料 } & ヤング象 $(\mathrm{MPa})$ & ポアソン比 \\
\hline FR-4 & $1.82 \times 10^{4}$ & 0.19 \\
\hline モールド樹脂 & $1.55 \times 10^{4}$ & 0.25 \\
\hline BTレジン & $1.90 \times 10^{4}$ & 0.20 \\
\hline はんだ & $3.86 \times 10^{3}$ & 0.37 \\
\hline
\end{tabular}

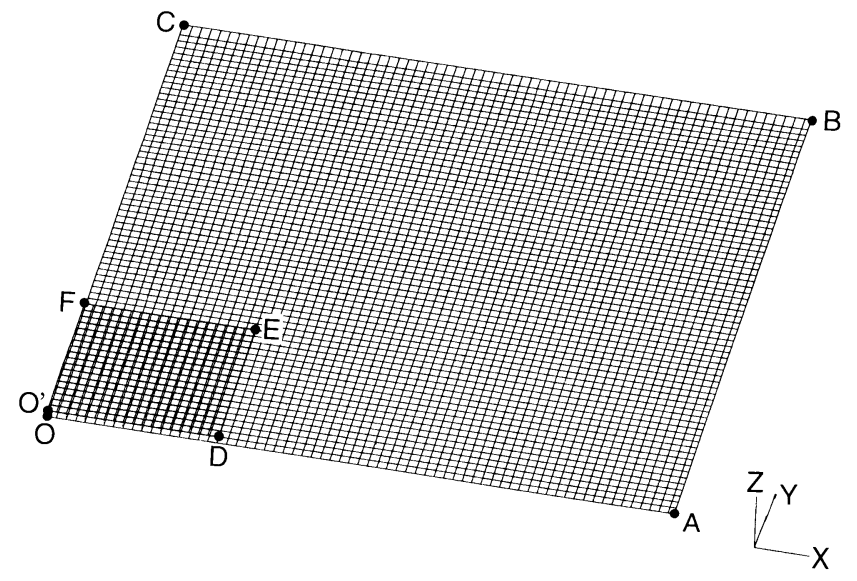

図7. 全体解析の要素分割図

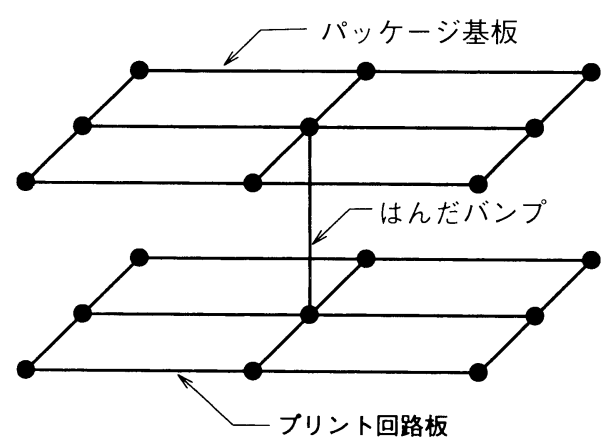

図8. はんだバンプ周辺の要素分割拡大図

ント回路板ともに，はんだ接合側の表面の位置でモデル化 し，はんだバンプの高さを忠実に表現するようにした。ま た,パッケージ基板にモールド樹脂が重なっている部分は, シェル要素を複層に配置した。すなわち同一面上に節点を 共有するシェル要素を二重定義することによりモデル化し た。

はんだバンプはその形状を 3 次元的にモデル化すること が望ましいが，使用計算機の能力の点からはり要素でモデ ル化することを検討した。まず図 2 に示す225個のはんだ バンプの代わりに，図 9 に示すように基板中心および最も 外側のはんだバンプ計 9 個に数を減らした簡易解析モデル を考え，はんだバンプを 8 節点アイソパラメトリック立体 要素，他は 4 節点線形シェル要素を用いてモデル化した。

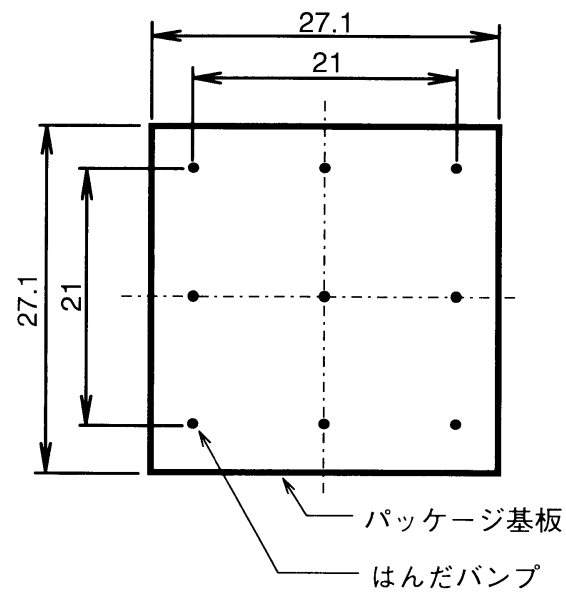

図9. 簡易解析のはんだバンプ位置 


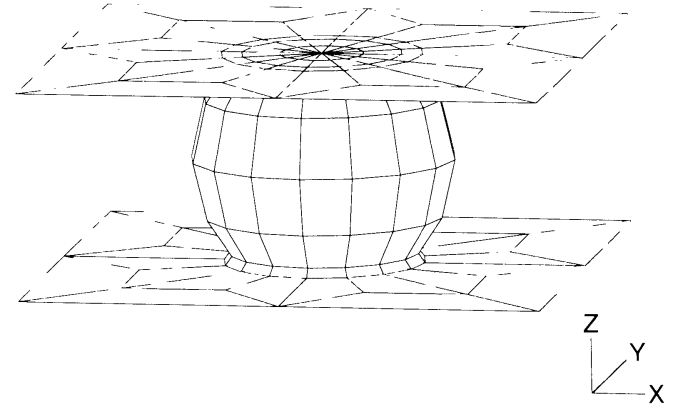

図10. 立体要素を用いた簡易解析モデルのはんだバンプ周辺の 要素分割図

簡易解析モデルのはんだバンプ周辺の要素分割図を図10に 示す。この簡易解析モデルの基板中心部に図 5 に示す強制 変位を与えて弾性解析を行った。解析の結果, はんだバン プ周辺の基板の変位は各節点の $z$ 軸方向変位が支配的で, x軸方向およびy軸方向変位はきわめて微小であることが わかった。次にはんだバンプを直径 $0.6 \mathrm{~mm}$ の 3 次元弾性は り要素でモデル化した簡易解析モデルを用い，同様な解析 を行った。この結果を立体要素を用いた解析結果と, 詳細 解析で強制変位を与えた基板節点の Z 軸方向变位で比較し た。その結果，両者の差は $5 \%$ 末満であった。以上の点か ら全体解析でははんだバンプをはり要素でモデル化するこ とが十分可能であると判断し，直径 $0.6 \mathrm{~mm}$ の 3 次元弾性は り要素でモデル化した。

全体解析の結果から, BGAパッケージの最も外側の角 部のはんだバンプにおいて相当ひずみが最大となることが わかった。

\section{2 はんだバンプ部の詳細解析}

全体解析で，相当ひずみが最大になったはんだバンプ 1 個分とその周辺の基板を解析対象として詳細解析を行っ た。詳細解析の要素分割図を図11に示す。使用した要素は 8 節点アイソパラメトリック立体要素である。詳細解析モ デルでは，ひずみが集中すると予想される領域を特に細か く要素分割した。

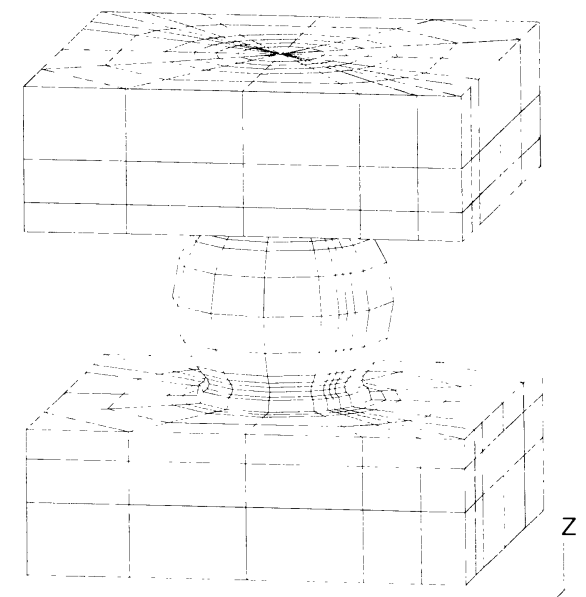

図11． 詳細解析の要素分割図

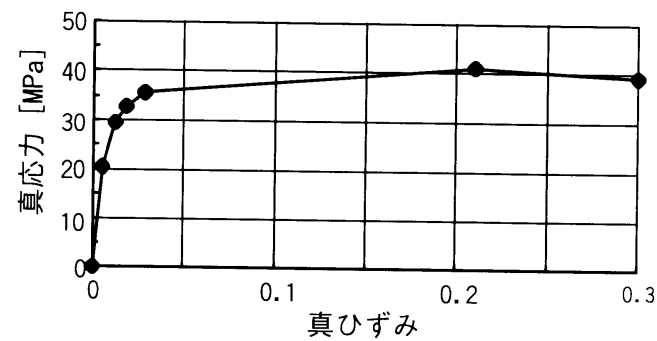

図12.はんんだ応カーひずみ関係

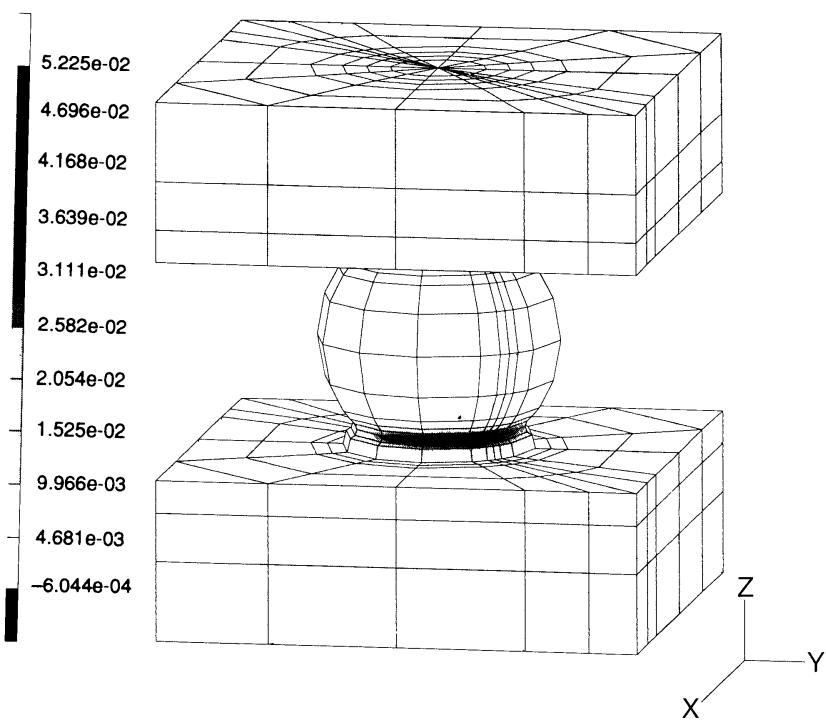

図13. はんだバンプ部の相当塑性ひずみの分布

材料物性值は全体解析と同じであるが，はんだについて は塑性を考慮した。はんだの応力ーひずみ関係は，引張試 験で求めた応力ーひずみ曲線を多直線近似して用いた。引

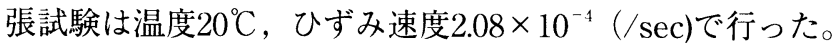
解析に用いたはんだの応力ーひずみ関係を図12に示す。

解析は, 図11でプリント回路板とパッケージ基板のそれ ぞれはんだが接合されている面上の最も外側の節点8個, 計16個の節点に対し，全体解析で求めた変位の $\mathrm{x}, \mathrm{y}, \mathrm{z}$ 方 向成分を強制変位として与えて行った。

詳細解析で求めたはんだバンプ部の相当塑性ひずみの分 布を図13に示す。図13から相当塑性ひずみははんだバンプ 右下のはんだ接合界面端近傍のはんだ側で最大になってい る。この位置は疲労試験のき裂発生位置と一致する。

\section{4. 疲労強度評価}

はんだ接合部の疲労強度を相当塑性ひずみ範囲をパラメ ータとするManson-Coffin則で評価することを検討しだば。 相当塑性ひずみ範囲 $\Delta \varepsilon_{p \ltimes r}$ は 1 負荷サイクルにおける最大相 当塑性ひずみと最小相当塑性ひずみの差として定義され る。また，相当塑性ひずみ $\varepsilon_{p e q}$ は相当塑性ひずみ増分 $d \varepsilon_{p e q}$ をひずみ経路に沿って積分した值で，次式で評価されるき。

$$
\varepsilon_{p c q}=\int d \varepsilon_{p c q}
$$

$$
d \varepsilon_{p e q}=\sqrt{\frac{2}{3}}\left\{d \varepsilon_{p x}{ }^{2}+d \varepsilon_{p y}{ }^{2}+d \varepsilon_{p z}{ }^{2}+2\left(d \gamma_{p x y}{ }^{2}+d \gamma_{p y z}{ }^{2}+d \gamma_{p z x}{ }^{2}\right)\right\}^{\frac{1}{2}}
$$




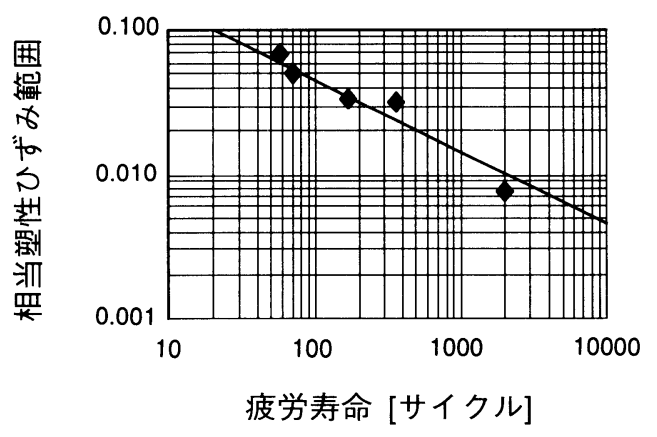

図14. 相当塑性ひずみ範囲と疲労寿命の関係

そこで相当塑性ひずみが最も集中するはんだ表面の点か ら内部にはんだの 3 結晶粒分, $50 \mu \mathrm{m}$ 入った点で相当塑性 ひずみ範囲を求めだ。はんだ表面から $50 \mu \mathrm{m}$ 内部に入った 点を評価点としたのは，応力およびひずみの解析結果に対 するはんだ接合界面端近傍の要素分割による影響を軽減す るためである。

相当塑性ひずみ範囲と疲労寿命の関係を図14に示す。図 14に示すように，相当塑性ひずみ範囲と疲労寿命の関係は 一つの直線で比較的よく近似され，相当塑性ひずみ範囲を パラメータとするManson-Coffin則で良好に評価できるこ とがわかった。図14の近似直線から, 以下の疲労強度評価 式が得られた。

$$
N_{f}=0.185 \times \Delta \varepsilon_{p e q}^{-2.027}
$$

\section{5. 結 言}

本研究では，実装基板に繰り返しそり変形を与えて BGAはんだ接合部の機械的疲労試験を行うとともに，有 限要素法を用いて応力・ひずみ解析を行い，BGAはんだ 接合部の疲労強度評価則を検討した。

その結果，基板が繰り返しそり変形を受けるBGAはん だ接合部の疲労強度は，ひずみが集中するはんだ部の相当 塑性ひずみ範囲をパラメータとするManson-Coffin則を用 いて良好に評価できることを示し，その疲労強度評価式を 決定した。

(1997.7.22-受理 1997.11.10-再受理)

\section{文献}

1) 海老原理徳：“BGAパッケージはんだ接合部の熱疲労強度 評価”, 回路実装学会誌, Vol.10, No.6, pp.394-400 (1995).

2) 于強, 白鳥正樹：“マイクロエレクトロニックパッケージは んだ接合部のクリープ／低サイクル疲労強度評価”，日本機 械学会研究協力部会RC-128「電子デバイス/電子機器の強 度信頼性評価に関する研究分科会」報告書, pp.245-340 (1996).

3）北野誠, 河合末男, 清水一男：“面付実装形ICパッケージは んだ接合部の熱疲労強度評価”, 日本機械学会論文集, 56 巻525号, A, pp.1140-1147 (1990).

4) J.H.Lau, D.W.Rice and S.Erasmus : "Thermal Fatigue Life of 256-pin, 0.4mm Pitch Plastic Quad Flat Pack (QFP) Solder Joints", Proceeding of the 1992 Joint ASME/JSME Conference on Electronic Packaging, Advances in Electronic Packaging, pp.855-863 (1992).

5) M.Shiratori, Q.Yu and S.Wang: "A Computational and Experimental Hybrid Approach to Creep-Fatigue Behavior of Surface-Mounted Solder Joints", Proceeding of the International Intersociety Electronic Packaging Conference, EEP-Vol.10-1, Advances in Electronic Packaging, pp.451-457 (1995).

6) 熊沢鉄雄, 河野竜治, 北野誠, 木本良輔：“はんだボール接 合部の疲労寿命の検討”, 第 9 回回路実装学術講演大会講演 論文集, pp.103-104 (1995).

7) Y.Ebihara, K.Nakane and S.Cai : "Fatigue Life Prediction of BGA Solder Joints under Thermal Cyclic Loads", Proceeding of the 5th International Conference on Computational Engineering Science, Hawaii, pp.628-633 (1995).

8) 益田森治, 室田忠雄 : “改訂工業塑性力学”, 養賢堂, p.123 (1993).

9) 海老原理徳, 小俣宣行：“BGAパッケージはんだ接合部の 熱疲労強度解析”, 日本機械学会第 9 回計算力学講演会講演 論文集, pp.509-510 (1996). 